\title{
KEMANDIRIAN HAKIM DALAM PERSPEKTIF NEGARAWAN
}

\author{
Barhamudin $^{1}$ dan Abuyazid Bustomi ${ }^{2}$ \\ ${ }^{1}$ Fakultas Hukum Universitas Palembang \\ E-mail: bsuryaigama@yahoo.com \\ ${ }^{2}$ Fakultas Hukum Universitas Palembang \\ E-mail: Abuyazid.bustomi13.ab@gmail.com
}

\begin{abstract}
The purpose of this study was to determine the independence of judges in accordance with Law Number 48 of 2009 in Statesperson's Perspectives. The research is a normative legal research that uses the law approach and the concept approach and data sources in this study are Primary Legal Materials; Secondary Legal Material and Tertiary Legal Material, the study found that all Judges must have the quality of statesmanship not just Constitutional judges, even those judges must behave and behave as statesmen, because judges are required to be impartial or independent in their duties to uphold truth based on law and justice. Judges must have the knowledge and expertise in administering the state, sufficient field of experience, and commitment to carry out and oversee the life of the state in accordance with the constitutional corridor. The judges are essentially statesmen, if seen from their duties and functions to uphold law and justice, not for the interests of others other than for the interests of the state, are not the elements of the state reflected in the interests of the people. Judges have the freedom to carry out their duties judicially and only answer to God.
\end{abstract}

Keywords: Independence Statesman Judges

\begin{abstract}
Abstrak
Penelitian ini bertujuan untuk mengetahui kemandirian hakim menurut Undang-undang Nomor 48 Tahun 2009 dalam Perspektif negarawan. Metode yang digunakan adalah metode penelitian hukum normatif dengan menggunakan pendekatan undang-undang dan pendekatan konsep. Hakim harus memiliki kualitas kenegarawanan bukan hanya hakim Konstitusi saja, bahkan para hakim harus bersikap dan berprilaku sebagai seorang negarawan, oleh karena hakim dituntut tidak memihak atau independen dalam tugasnya menegakan kebenaran yang didasarkan hukum dan keadilan. Hakim harus memiliki pengetahuan dan keahlian penyelenggaraan negara, memiliki pengalaman yang cukup, serta komitmen untuk melaksanakan dan mengawal kehidupan bernegara sesuai dengan koridor konstitusi. Para hakim pada hakikatnya adalah negarawan, jika dilihat dari tugas dan fungsinya menegakan hukum dan keadilan, bukan untuk kepentingan selain dari kepentingan negara, unsur negara tercermin dari kepentingan rakyat. Hakim memiliki kebebasan dalam melaksanakan tugasnya secara judicial dan hanya bertanggung jawab kepada Tuhan.
\end{abstract}

Kata Kunci : Kemandirian Hakim Negarawan

\section{PENDAHULUAN}

Salah satu unsur terpenting dalam struktur ketatanegaraan suatu negara adalah kekuasaan kehakiman. kekuasaan yang merupakan tiang penyangga suatu negara apapun bentuk negara itu. Dalam negara hukum kekuasaan dituntut harus bebas atau merdeka dari pengaruh apapun dan siapapun. Oleh karena itu, kekuasaan kehakiman juga harus mandiri, terpisah dari kekuasaan lainnya yaitu kekuasaan legislatif dan kekuasaan 
Barhamudin dan Abuyazid Bustomi, Kemandirian Hakim dalam Perspektif Negarawan, Halaman 269-284 eksekutif, untuk menjamin bagi Kehakiman. ${ }^{1}$ sedangkan Komisi tegaknya hukum dan keadilan. Yudisial sebagai penunjang terhadap Tegaknya hukum dan keadilan terwujud kekuasaan kehakiman. Kekuasaan atau tidak tercermin dalam kemandirian dan kemerdekaan hakim, baik sendirisendiri maupun sebagai institusi dari berbagai pengaruh yang berasal dari luar diri hakim berupa intervensi yang bersifat mempengaruhi bai secara halus, maupun dengan tekanan, paksaan, kekerasan, atau balasan karena kepentingan politik dan ekonomi tertentu dari pemerintah atau kekuatan politik yang berkuasa, kelompok atau golongan.

Hakim sebagai bagian dari penegak hukum dan keadilan dituntut untuk mengenal, menggali, merasakan serta memahami, nilai-nilai hukum dan keadilan yang hidup dalam masyarakat sebagaimana dikehendaki dalam Undang-Undang Nomor 48 Tahun 2009 tentang kekuasaan kehakiman dengan mengintegrasikan diri dalam masyarakat guna benar-benar mewujudkan fungsi hukum dalam menegakkan keadilan.

Kekuasaan kehakiman dilakukan oleh lembaga-lembaga peradilan seperti Mahkamah Agung dan Mahkamah Konstitusi sebagai pelaku Kekuasaan kehakiman yang merdeka, diperlukan untuk menjamin impartiality (ketidakberpihakan) dan fairness (kejujuran, keadilan) dalam memutus perkara, termasuk perkara-perkara yang langsung atau tidak langsung melibatkan kepentingan cabang-cabang kekuasaan yang lain. Pengadilan atau hakim harus independen tidak hanya terhadap cabang kekuasaan lain, tetapi juga dengan pihak-pihak yang berperkara. Hakaim akan menjadi menjadi sorotan utama terkait dengan masalah penegakan hukum dalam suatu negara, karena sebagaimana sering kita dengar bahwa hakim atau pengadilan adalah benteng terakhir penegakan hukum dan keadilan bagi pencari keadilan. Oleh karena itu masyarakat menaruh harapan yang sangat besar kepada hakim yang benar-benar memiliki integritas dan profesionalisme, sehingga tindakan dan tingkah lakunya menunjukan keemandirian, memiliki integritas moral, serta pada kemampuannya memberikan putusan yang baik. Kemandirian hakim merupakan prinsip yang melekat dalam

\footnotetext{
${ }^{1}$ Pasal 1 Undang-Undang Nomor 48 Tahun 2009 tentang Kekuasaan Kehakiman
} 
Barhamudin dan Abuyazid Bustomi, Kemandirian Hakim dalam Perspektif Negarawan, Halaman 269-284

hakikat fungsi hakim, apalagi hakim pada umummya dinegara manapun dan kapan pun adalah pejabat negara. Hakim merupakan pejabat negara yang khusus atau istimewa karena dalam kedudukan sebagai hakim, seorang hakim itu adalah penjaga dan benteng terakhir untuk tetap berlangsungnya eksistensi suatu negara, simbol beradab atau tidaknya suatu bangsa.

Sebagai pihak yang diharapkan memberikan pemecahan terhadap setiap perkara yang diajukan kepadanya. Kemandirian mencakup sikap netral, menjaga jarak yang sama dengan semua pihak yang terkait dengan perkara, dan tidak mengutamakan salah satu pihak, serta penghayatan yang mendalam mengenai keseimbangan antara kepentingan yang terkait dengan perkara. Namun dalam praktik saat ini sering kali dijumpai para pencari keadilan merasa tidak puas dan kecewa terhadap kinerja hakim yang dianggap tidak bersikap mandiri dan kurang profesional. Banyaknya intervensi dan tekanan pihak luar terhadap hakim, terkadang membuat kinerja hakim tidak lagi optimal, atau bahkan memilih bersikap oportunis. Tidak semua hakim dapat menyatakan yang benar adalah benar dan yang salah adalah salah. ${ }^{2}$

Kewenangan dan tugas luhur hakim sebagai penegak hukum dan keadilan yang dipertanggungjawabkan kepada Allah Tuhan Yang Maha Esa, menuntut suatu persyaratan khusus yang harus dimiliki oleh seorang hakim. Dalam peraturan perundang-undangan mensyaratkan sifat-sifat yang harus dimiliki oleh seorang hakim seperti: jujur, merdeka, bebas dari pengaruh baik dari dalam maupun dari luar, adil, dan berkelakuan tidak tercela. Sifat ini pada dasarnya adalah selaras dan merupakan butir-butir ajaran agama. Oleh karena itu, penyimpangan yang dilakukan oleh hakim dalam menjalankan profesi pada dasarnya adalah penyimpangan terhadap agama, apapun agama yang dianut karena pada dasarnya semua agama mengajarkan umatnya untuk melaksanakan sifat-sifat tersebut. Dari latar belakang sebelumnya maka penulis akan mengkaji lebih dalam terkait independensi hakim, untuk mengetahui bagaimana kemandirian hakim dalam perspektif negarawan.

Penelitian ini merupakan penelitian hukum normatif yang menggunakan

2 Wildan Suyuti Mustofa, Kode Etik Hakim, Jakarta: Kencana, 2013, hlm. 97. 
Barhamudin dan Abuyazid Bustomi, Kemandirian Hakim dalam Perspektif Negarawan, Halaman 269-284

pendekatan undang-undang dan pendekatan konsep dan sumber data dalam penelitian ini adalah sebagai berikut: ${ }^{3}$ Bahan Hukum Primer, yaitu bahan-bahan yang mengikat data bahan utama dalam membahas suatu permasalahan. Bahan hukum primer dalam penelitian ini terdiri dari UUD 1945 dan peraturan perundangundangan yang lain; Bahan Hukum Sekunder, yaitu bahan yang menjelaskan bahan hukum primer, meliputi hasil-hasil penelitian dan pendapat pakar hukum dan Bahan Hukum Tersier, yaitu bahan hukum tambahan atau bahan yang menjelaskan bahan hukum primer dan bahan hukum sekunder. Adapun bahan hukum tersier yang digunakan dalam penelitian ini yang berupa kamus dan ensiklopedia. Selanjutnya dianalisis dengan menggunakan metode deskriptif kualitatif, yaitu digambarkan dengan kata-kata atau kalimat, untuk diambil suatu kesimpulan.

\section{PEMBAHASAN}

Di Indonesia cita-cita untuk menjadikan kekuasaan kehakiman menjadi kekuasaan yang terpisah dari

\footnotetext{
3 Amiruddin, Pengantar Metode Penelitian Hukum, Jakarta: Raja Grafindo Persada, 2012, hlm. 32.
}

kekuasaan yang lainnya sudah terjadi sejak dulu. ${ }^{4}$ Kekuasaan kehakiman yang terpisah berkait erat dengan kekuasaan kehakiman yang merdeka. Kekuasaan Kehakiman adalah kekuasaan negara yang merdeka untuk menyelenggarakan peradilan guna menegakkan hukum dan keadilan berdasarkan Pancasila dan Undang-Undang Dasar Negara Republik Indonesia Tahun 1945, demi terselenggaranya Negara Hukum Republik Indonesia. ${ }^{5}$

Prinsip menegakkan hukum dan keadilan ini menghendaki kekuasaan kehakiman yang bebas dari campur tangan pihak manapun dan dalam bentuk apapun sehingga dalam menjalankan tugas dan kewajibannya, ada jaminan ketidakberpihakan kekuasaan kehakiman kecuali terhadap hukum dan keadilan. Fungsi ini lazimnya dijalankan oleh suatu lembaga yang disebut dengan lembaga peradilan, yang berwenang melakukan pemeriksaan, penilaian dan memberikan putusan terhadap konflik. Wewenang yang sedemikian itulah yang disebut sebagai kekuasaan kehakiman yang dalam praktiknya dilaksanakan oleh hakim. Di antara para penegak hukum yang lain posisi hakim adalah

4 Rimdan, Kekuasaan Kehakiman, Jakarta: Kencana Prenada Media Grup, 2012, hlm. 300.

${ }^{5}$ Pasal 1 Undang-Undang Nomor 48 Tahun 2009 tentang Kekuasaan Kehakiman 
Barhamudin dan Abuyazid Bustomi, Kemandirian Hakim dalam Perspektif Negarawan, Halaman 269-284

istimewa. Hakim adalah kongkretisasi hukum dan keadilan yang abstrak, bahkan ada yang menggambarkan hakim sebagai wakil tuhan dibumi untuk menegakkan hukum dan keadilan.

Menurut Jimly Asshiddiqie, kekuasaan kehakiman merupakan kekuasaan yang lahir dari nilai-nilai yang tumbuh di masyarakat. Sejak zaman awal kemerdekaan hingga saat ini, kekuasaan kehakiman di Indonesia mengalami perkembangan yang cukup dinamis, ditandai dengan perubahan perundang-undangan yang mengaturnya, hingga lembaga-lembaga peradilan yang kian eksklusif dan komprehensif. ${ }^{6}$

Perjalanan ketatanegaraan Indonesia sejak merdeka 17 Agustus 1945, telah mengalami pasang surut baik dalam gagasan, tatanan maupun terapannya. Sejarah demokrasi pasca kemerdekaan oleh para ahli sering dibagi ke dalam beberapa waktu, yaitu masa demokrasi liberal (1945-1959), demokrasi terpimpin (1959-1966) dan demokrasi pancasila (1967- sampai tumbangnya kekuasaan orde baru), secara historis dinamika itu dapat dilihat fakta sejarah konstitusionalnya, bahwa di Indonesia pernah diberlakukan beberapa konstitusi

\footnotetext{
6 Jimly Asshiddiqie, Pokok-pokok Hukum Tata Negara Indonesia, Jakarta: Buana Ilmu Populer, 2007, hlm. 510.
}

Undang-Undang Dasar (UUD) 1945, UUD RIS, Undang-Undang Dasar Sementara (UUDS) 1950, UUD 1945 dan sekarang Undang-Undang Dasar 1945 hasil amandemen tahun 1999$2002 .^{7}$

Di era Orde reformasi, tuntutan akan hukum yang berpihak kepada masyarakat, tegaknya hukum dan keadilan hal ini denga ditegaskannya dalam Pasal 1 ayat (3) Undang-Undang Dasar Negara Republik Indonesia Tahun 1945 setelah amandemen bahwa negara Indonesia adalah negara hukum.

Sejalan dengan ketentuan tersebut maka salah satu prinsip penting negara hukum adalah adanya jaminan penyelenggaran kekuasaan kehakiman yang merdeka, bebas dari pengaruh kekuasaan lainnya. Penegakan rule of law dalam pelaksanaan hukum merupakan syarat mutlak bagi berdirinya sebuah bangunan demokrasi. Terdapat 6 (enam) syarat-syarat dasar untuk terselenggaranya pemerintah yang demokratis dibawah rule of law, yaitu: Perlindungan Konstitusional, peradilan atau badan-badan kehakiman yang bebas dan tidak memihak, pemilihan umum yang bebas, kebebasan menyatakan pendapat,

kebebasan 
Barhamudin dan Abuyazid Bustomi, Kemandirian Hakim dalam Perspektif Negarawan, Halaman 269-284

berserikat/berorganisasi dan beroposisi, pendidikan kewarganegaraan. ${ }^{8}$

Dalam Undang-Undang Dasar Negara Republik Indonesia Tahun 1945 disebutkan pada pasal 24 bahwa kekuasaan kehakiman merupakan kekuasaan yang merdeka untuk menyelenggarakan peradilan guna menegakkan hukum dan keadilan yang dilakukan oleh sebuah Mahkamah Agung dan badan peradilan yang berada di bawahnya dalam lingkungan peradilan umum, lingkungan peradilan agama, lingkungan peradilan militer, lingkungan peradilan tata usaha negara dan oleh sebuah Mahkamah Konstitusi. Peradilan harus bersifat independen serta impartial (tidak memihak). Independensi dan imparsialitas/ketidakberpihakan

kekuasaan kehakiman ini harus dijamin oleh konstitusi, guna memudahkan langkah kekuasaan kahakiman melaksanakan fungsi utamanya, yaitu menegakkan keadilan.

Asas imparsial atau tidak memihak merupakan suatu bentuk pengertian dasar dari independensi kekuasaan kehakiman. Hakim haruslah tidak memihak dan independensi dan bebas dalam menentukan fakta serta

${ }^{8}$ Moh. Mahfud MD, Dasar dan Struktur Ketatanegaraan Indonesia, Jakarta: Rineka Cipta, 2000, hlm. 117. menerapkan hukum kepada fakta-fakta tanpa dipengaruhi oleh sumber manapun juga. Hakim bebas dalam memutuskan segala putusannya tanpa ada intervensi atau campur tangan pihak lain. Seorang hakim yang sangat bebas, tidak bersifat memihak dalam menjalankan tugas memutus suatu perkara di peradilan. Pasal 3 ayat 1 Undang-undang Nomor 48 Tahun 2009 yaitu dalam menjalankan tugas dan fungsinya, hakim dan hakim konstitusi wajib menjaga kemandirian peradilan.

Sebelum Amandemen UUD 1945 Kekuasaan kehakiman hanya dilakukan oleh Mahkamah Agung dan lembaga peradilan yang berada dibawahnya sedangkan pasca amandemen UUD 1945, kekuasaan kehakiman dilakukan oleh lembaga-lembaga kehakiman seperti hadirnya Mahkamah Konstitusi (Tahun 2003) dan Komisi Yudisial (Tahun 2004) sebagai lembaga yang turut serta sebagai pengawal tegaknya kekuasaan kehakiman. Secara struktural kedudukan antara Mahkamah Agung, Mahkamah Konstitusi, dan Komisi Yudisial berada dalam posisi sederajat. Namun secara fungsional peranan dari ketiga lembaga tersebut berbeda, jika Mahkamah Agung dan Mahkamah Konstitusi sebagai lembaga penegak 
Barhamudin dan Abuyazid Bustomi, Kemandirian Hakim dalam Perspektif Negarawan, Halaman 269-284

hukum, maka Komisi Yudisial adalah lembaga yang bertugas mengawasi para pelaksanaan kode etik dan perilaku menyimpang dari para hakim. Sebagaimana telah disebutkan diatas, bahwa hakim adalah jabatan istimewa dalam suatu negara, hakim penegak hukum dan keadilan serta simbol peradaban suatu bangsa dengan tegaknya keadilan. Tugas menegakan hukum dan keadilan bagi seorang hakim melampaui batas-batas negara, tidak terbatas pada warganegara suatu negara, disinilah peran seorang hakim menjadi simbol peradaban suatu negara atau bangsa.

Sebagaimana yang terjadi dalam sejarah Islam kita mencatat bahwa para hakim sangat independen dan berani dalam membuat keputusan, mereka tidak pernah ragu dalam memberi keputusan bahkan jika bertentangan dengan penguasa mereka. Hakim harus memperlakukan sama dan adil antara pihak yang bersengketa. Oleh para hakim hakim adalah orang yang jujur, taqwa dan mereka percaya bahwa Allah SWT mengetahui segala tindakan mereka.

Hakim tidak boleh terpengaruh dengan keadaan di sekeliling atau tekanan dari siapapun, bahkan pengaruh dari dirinya sendiri. Dalam hubungan ini
Allah telah berfirman dalam surat AlAn`am ayat 152 “ Apabila kamu mengatakan sesuatu, maka hendaklah kamu berlaku adil, sekalipun orang itu ada hubungan kerabat dengan kamu. ${ }^{9}$

Hakim yang independen dan mempunyai reputasi yang baik sangat dibutuhkan untuk menegakkan hukum dan keadilan. Untuk menjaga integritas peradilan, maka semua orang yang menempati posisi di lembaga peradilan harus menjalankan tugas mereka dengan adil dan tidak memihak. Khusus para hakim jika menunjukan sikap memihak atau diskriminasi dalam hal apa pun, dapat menghalangi terwujudnya tegaknya hukum dan keadilan dan membawa citra yang buruk pada lembaga peradilan.

Negara Indonesia adalah Negara hukum. Sebagai konsekuensi Negara hukum, maka Indonesia harus menghormati dan menjunjung tinggi prinsip-prinsip Negara hukum. Salah satunya adalah prinsip pemisahan kekuasaan, menurut Monstesque dalam masalah pemisahan kekuasaan ia membedakannya dalam tiga bagian pemisahan kekuasaan dan biasanya dikenal dengan teori Trias Politc

9 Departemen Agama RI, Al-Qur'an dan Terjemah., Jakarta: Maghfirohal Pustaka, 2006, hlm. 149. 
Barhamudin dan Abuyazid Bustomi, Kemandirian Hakim dalam Perspektif Negarawan, Halaman 269-284

Undang-Undang Dasar Republik

Indonesia 1945, Pasal 1 ayat (3).

diantaranya kekuasaan legislatif,

eksekutif, dan yudikatif. Kekuasaan

kehakiman merupakan kekuasaan negara

yang merdeka untuk menyelenggarakan

peradilan guna menegakkan hukum dan

keadilan berdasarkan pancasila,demi terselenggaranya Negara Hukum

Republik Indonesia. Oleh karena itu, prinsip lain yang juga dianut oleh

Negara Kesatuan Republik Indonesia dalam menjalankan pemerintahannya adalah adanya jaminan penyelenggaraan kekuasaan kehakiman yang merdeka, bebas dari kekuasaan lainnya untuk menyelenggarakan peradilan guna menegakkan hukum dan keadilan. Kekuasaan adalah kemampuan seseorang atau sekelompok manusia untuk mempengaruhi tingkah laku seseorang atau sekelompok lain sedemikian rupa sehingga tingkah laku itu menjadi sesuai dengan keinginan dan tujuan dari orang yang mempunyai kekuasaan itu. ${ }^{10}$

Undang-Undang Nomor 48 Tahun 2009 mencerminkan keinginan yang kuat dan konsekuen untuk menciptakan kekuasaan kehakiman yang benar-benar

10 Miriam Budiardjo, Dasar-Dasar Ilmu Politik, Jakarta: Gramedia Pustaka Utama, 2008, hlm. 17. mandiri dan merdeka dari sekalian intervensi pihak luar yang dapat merusak pada keadilan, kemanfaatan, dan kepastian hukum. ${ }^{11}$

Pasal 1 Ayat (1) Undang-Undang Nomor 48 Tahun 2009 menjelaskan bahwa Kekuasaan kehakiman adalah kekuasaan negara yang merdeka untuk menyelenggarakan peradilan guna menegakkan hukum dan keadilan berdasarkan pancasila dan UndangUndang Dasar Negara Republik Indonesia Tahun 1945, demi terselenggaranya Negara Hukum Republik Indonesia.

Pada negara hukum yang demokratislah kekuasaan kehakiman yang merdeka akan dapat diwujudkan dan bukan hanya uraian kata-kata semu di dalam konstitusi. Meskipun demikian, perlu dipahami bahwa kekuasaan kehakiman tidak berkaitan dengan pembuatan hukum (law making), walaupun hakim diberikan kebebasan untuk dapat menemukan hukum karena kasus tertentu yang tidak ada ketentuan dalam teks peraturan perundangundangan. Akan tetapi, hal itu bukan dikategorikan sebagai pembuatan hukum, namun itu diartikan sebagai

\footnotetext{
${ }^{11}$ Josef M. Monteiro, Lembaga-lembaga Negara setelah. Amandemen UUD 1945, Yogyakarta: Pustaka Yustisia, 2014, hlm. 97.
} 
Barhamudin dan Abuyazid Bustomi, Kemandirian Hakim dalam Perspektif Negarawan, Halaman 269-284 penemuan hukum yang meliputi Konstitusi. Amandemen juga penafsiran hukum dan kontruksi hukum. ${ }^{12}$

Kekuasaan kehakiman merupakan elemen penting dalam sebuah negara bangsa, karena kekuasaan kehakiman tersebut merupakan pilar ketiga dalam sistem sistem kekuasaan negara terutama modern. Pasal 3 ayat 1 , dalam menjalankan tugas dan fungsinya, hakim dan hakim konstitusi wajib menjaga kemandirian peradilan. Pasal 3 ayat 2, segala campur tangan dalam urusan peradilan oleh pihak lain di luar kekuasaan kehakiman dilarang, kecuali dalam hal-hal sebagaimana dimaksud dalam Undang-Undang Dasar Negara Republik Indonesia Tahun 1945.

Lembaga peradilan yang menjalankan kekuasaan kehakiman dalam Undang-Undang Dasar 1945 diatur dalam BAB 1X, Pasal 24, 24A, 24B, 24C, dan Pasal 25. Pada dasarnya, pasal-pasal yang berkaitan dengan kekuaasaan kehakiman ini mengalami perubahan melalui amandemen ketiga UUD 1945 pada tanggal 10 November 2001. Amandemen ketiga menetapkan kekuasaan kehakiman dilakukan oleh Mahkamah Agung dan Mahkamah

12 Ibid, hlm. 96. 
Barhamudin dan Abuyazid Bustomi, Kemandirian Hakim dalam Perspektif Negarawan, Halaman 269-284

doktrin separation of powers (pemisahan kekuasaan) yang harus dilakukan secara tegas agar cabang-cabang kekuasaan negara tidak saling mempengaruhi.

Sesungguhnya konsepsi independensi dan imparsialitas hakim tersebut mempunyai beberapa aspek atau dimensi, sebagaimana diatur dalam Pasal 5 ayat (2) dan (3) Undang-Undang Kekuasaan Kehakiman yang dapat dilihat secara fungsional, kelembagaan (institusi), maupun secara personal dari masing-masing hakim kebebasan fungsional menurut hukum tata negara mengandung larangan bagi kekuasaan negara lain untuk mengadakan intervensi dalam pemeriksaan perkara oleh hakim baik dalam pertimbangan maupun dalam penjatuhan putusan.

Independensi dan imparsialitas hakim harus diartikan secara luas tidak hanya terbatas pada kebebasan dari campur tangan kekuasaan lainnya (eksekutif dan legislatif), tetapi juga kebebasan dari segala paksaan, direktiva atau rekomendasi dari pihak extra judicial. Ketentuan Pasal 3 ayat (3) Undang-Undang Kekuasaan Kehakiman yang menyatakan bahwa, pelanggaran terhadap Pasal 3 ayat (2) UndangUndang Kekuasaan Kehakiman yang mengatur larangan campur tangan dalam urusan peradilan oleh pihak lain di luar kekuasaan kehakiman, akan dipidana adalah merujuk pada direktiva atau paksaan maupun suap atau kolusi. Meskipun demikian, tidak berarti, bahwa kebebasan tersebut bersifat mutlak karena tentu saja dibatasi oleh hukum dan keadilan. Hakim memiliki kebebasan dalam melaksanakan tugasnya secara judicial dan hanya bertanggung jawab kepada Tuhan. Kebebasan hakim secara fungsional melekat dengan pertanggungjawaban (accountability) yang terbuka kepada masyarakat, sehingga hakim tidak hanya mempertanggungjawabkan pelaksanaan kebebasan fungsionalnya pada Tuhan. Independensi dan imparsialitas terutama menjadi lebih penting jika dihadapkan dengan kekuatan politik yang berpengaruh dari pihak yang mengangkat atau memilih hakim.

Menurut ketentuan Pasal 14 UU Nomor 2 Tahun 1986 tentang Peradilan Umum dan UU Nomor 5 Tahun 1986 tentang Peradilan Tata Usaha Negara, syarat untuk menjadi hakim adalah: ${ }^{14}$

1. Warga Negara Indonesia;

2. Bertaqwa kepada Tuhan YME;

${ }^{14}$ Jimly Asshiddiqie, Pokok Pikiran tentang Penyempurnaan Sistem Pengangkatan dan Pemberhentian Hakim Indonesia, hlm. 2-3. 
Barhamudin dan Abuyazid Bustomi, Kemandirian Hakim dalam Perspektif Negarawan, Halaman 269-284

3. Setia kepada Pancasila dan UUD 1945

4. Bukan bekas anggota organisasi terlarang;

5. Pegawai negeri;

6. Sarjana Hukum;

7. Berumur serendah-rendahnya 25 tahun;

8. Berwibawa, jujur, adil, dan berkelakuan tidak tercela.

Kedelapan syarat tersebut, sebagian terbesar termasuk kategori persyaratan yang bersifat administratif dalam arti cukup dipenuhi dengan menunjukkan bukti-bukti yang bersifat administratif. Yang terukur secara lebih lebih teknis adalah syarat-syarat yang bersifat profesional, seperti menyangkut ketrampilan melakukan analisis hukum, melakukan perdebatan argumentatif, dan sebagainya. Di samping itu, diperlukan juga adalah syarat-syarat personal yang bersifat kualitatif, seperti syarat taqwa terhadap Tuhan YME, integritas kepribadian, berwibawa, jujur, adil, dan berkelakuan tidak tercela. Syarat-syarat personal dan professional demikian perlu lebih dirinci untuk menjamin bahwa hakim yang diangkat benar-benar mereka yang tepat menduduki jabatan terhormat ini. ${ }^{15}$

\footnotetext{
15 Ibid
}

Untuk mengubah wajah hakim dan lembaga peradilan di masa mendatang, kedudukan hakim sebagai pejabat kehormatan perlu dikembangkan dengan memantapkan para penyandangnya sebagai pejabat Negara. Karena itu, perlu diadakan perubahan terhadap rumusan persyaratan hakim tersebut dengan melengkapinya secara lebih rinci dan dengan mengubah syarat ke-5 dan ke-7. Syarat ke-5 (syarat pegawai negeri) sebaiknya ditiadakan, sedangkan syarat ke-7 diubah dari persyaratan usia minimum 25 tahun menjadi usia minimum-maksimum 40 tahun-70 tahun.

Mengapa hakim tidak boleh dikaitkan dengan pegawai negeri? Pegawai negeri harus dibedakan dari penyandang fungsi kekuasaan negara (governing function) di bidang penghakiman yang lebih tepat disebut pegawai negara atau pejabat negara sebagai lawan kata pejabat negeri. Pegawai negeri pada pokoknya menduduki jabatan negeri, sedangkan jabatan negara diduduki oleh pejabat negara. Hakim secara sendiri-sendiri membuat keputusan dan menjatuhkan sanksi atas nama negara. Hakim diberi kewenangan atas nama negara untuk membebani warga negara dengan hak dan kewajiban yang dapat dipaksakan 
Barhamudin dan Abuyazid Bustomi, Kemandirian Hakim dalam Perspektif Negarawan, Halaman 269-284

daya ikatnya. Sedangkan pegawai negeri tidak diberi kewenangan semacam itu kecuali atas perintah pejabat negara yang menjadi atasannya. Oleh karena itu, mengaitkan jabatan hakim dengan pegawai negeri merupakan kesalahkaprahan yang harus dihentikan dan diperbaiki. ${ }^{16}$ Seseorang yang diangkat menjadi hakim, dapat saja mempunyai status sebagai pegawai negeri, tetapi tidak mutlak menjadi syarat eksklusif dalam arti yang bukan pegawai negeri diabaikan haknya untuk menjadi hakim meskipun yang bersangkutan memenuhi segala persyaratan lebih dari calon yang berasal dari pegawai negeri. Yang justru lebih penting dijadikan syarat bukanlah statusnya sebelum diangkat menjadi hakim, tetapi yang lebih utama justru adalah kuantitas dan kualitas peran dan pengalamannya di bidang hukum yang sangat penting baginya untuk diangkat menjadi hakim. Oleh sebab itu, sebaiknya di masa yang akan datang, diadakan syarat berpengalaman sekurang-kurangnya $10 \quad$ tahun menjalankan profesi hukum. Dengan demikian, yang dapat menjadi calon hakim adalah pegawai negeri yang bekerja di bidang hukum, dosen hukum, advokat, jaksa, konsultan hukum,

${ }^{16}$ Ibid. hlm. 3 pembela umum, notaries, aktifis hukum dan hak asasi manusia, pengamat, penulis dan kolumnis bidang hukum, dan pelbagai professional hukum lainnya. ${ }^{17}$

Khusus mengenai Hakim Agung dan Hakim Konstitusi diusulkan hendaknya berusia antara 60 tahun sampai dengan 70 tahun. Dengan demikian, seorang yang diangkat menjadi Hakim Agung dan juga Hakim Konstitusi sudah benarbenar orang yang matang, baik dari segi kepribadiannya, dari segi pengetahuan dan pengalamannya, serta kualitas kenegarawanannya. Seorang Hakim Agung atau Hakim Konstitusi yang masih muda, biasanya lebih sulit melepaskan diri dari hasrat-hasrat keduniaan, seperti nafsu jabatan dan sebagainya. ${ }^{18}$

Semua hakim harus memiliki kualitas kenegarawanan bukan hanya hakim Konstitus saja, bahkan para hakim itu harus bersikap dan berprilaku sebagai seorang negarawan, oleh karena hakim dituntut tidak memihak atau independen dalam tugasnya menegakan kebenaran yang didasarkan hukum dan keadilan.

Dari sisi gramatikal, negarawan adalah orang yang memiliki pengetahuan dan keahlian penyelenggaraan negara, medan pengalaman yang cukup, serta

\footnotetext{
${ }^{17}$ Ibid

${ }^{18}$ Ibid. hlm. 3
} 
Barhamudin dan Abuyazid Bustomi, Kemandirian Hakim dalam Perspektif Negarawan, Halaman 269-284

komitmen untuk melaksanakan dan mengawal kehidupan bernegara sesuai dengan koridor konstitusi. Negarawan juga dapat diartikan sebagai sosok yang visioner,berorientasi jangka panjang, mengutamakan

kesejahteraan masyarakat, mampu berlaku egaliter serta adil dan mengayomi semua komponen bangsa. ${ }^{19}$

Berdasarkan peraturan perundangundangan istilah Negarawan secara tegas hanya ditujukan pada Hakim Mahkamah Konstitusi sebagaimana disebutkan dalam Pasal 24C ayat (5) UUD 1945 yang bunyinya Hakim Konstitusi harus memiliki integritas dan kepribadian yang tidak tercela, adil, negarawan yang menguasai konstitusi.

Istilah negarawan yang dalam bahasa Inggris disebut "Statesman." Menurut Edmund Burke, seorang filusuf Inggris memberikan makna Negarawan seorang yang melihat masa depan dan bertindak pada prinsip-prinsip yang ditetapkan dan untuk keabadian. ${ }^{20}$ Sedangkan berdasarkan kamus MerriamWebster, negarawan adalah "orang yang aktif mengelola pemerintahan dan membuat kebijakan-kebijakan" (one actively engaged in conducting

19 https://kastara.id/27/02/2019/mencari-hakimnegarawan-yang-ideal/

20 Ibid the business of a government or in shaping its policies). Apabila ditelaah secara cermat tidak ada pengertian (begrip) secara jelas mengenai negarawan di dalam berbagai peraturan perundang-undangan, walaupun disebutkan secara jelas bahwa hakim Mahkamah Konstitusi merupakan negarawan sebagaimana istilah itu dimuat dalam UUD 1945.

Sesungguhnya istilah negarawan sendiri tidak jauh berbeda dengan politisi, namun apabila ditarik intinya, negarawan mempunyai pola pikir yang visioner dalam rangka mengelola negara menjadi lebih baik dengan menanggalkan kepentingan pribadi. Berbeda dengan politisi yang berpikir pragmatis yang orientasinya terletak pada keuntungan individu atau kelompoknya. Negarawan sepenuhnya berpikir untuk kepentingan rakyat, sedangkan politisi selalu berbicara kepentingan politik, entah tujuan pribadi maupun kelompok atau golongan. Oleh karenanya tepat jika para hakim itu pada hakikatnya adalah negarawan, jika dilihat dari tugas dan fungsinya menegakan hukum dan keadilan, bukan untuk kepentingan yang lain selain dari untuk kepentingan negara, bukankah unsur negara itu tercermin dari 
Barhamudin dan Abuyazid Bustomi, Kemandirian Hakim dalam Perspektif Negarawan, Halaman 269-284

kepentingan rakyat. Adapun ciri-ciri

dari seorang negarawan yaitu $:^{21}$

1. Memiliki kemampuan yang sangat cemerlang dan jeli; lebih merupakan bakat yang terpadu dengan keberanian melawan arus dan bertekad melakukan perubahan dan pembaruan struktural.

2. Berusaha memasuki hal-hal baru secara total, memilih menjadi pelopor atau pionir.

3. Karena yang di kemukakan adalah hal yang total baru, maka konsep yang di kemukakan menjadi mengejutkan dan meragukan pihakpihak yang masih berpikir dalam pola lama.

4. Mampu menawarkan solusi secara tuntas, serta reformasi/revolusi total yang positif dan konstruktif, hingga menawarkan konsep dan aksi menghentikan krisis besar yang melanda satu bangsa atau beberapa bangsa.

5. Mampu menawarkan harapan dan peluang nyata, membangun harga diri dan bernilai tinggi.

6. Berani menghadapi risiko bertentangan dengan rezim dan atau kekuatan yang berkuasa.

Seorang negarawan selalu memikirkan nasib bangsa dan negara sebagai suatu kesatuan yang utuh, serta tidak mementingkan secara ribadi/kelompok politiknya, namun mementingkan kepentingan bangsa di atas segalanya. Seorang negarawan harus mempertaruhkan dirinya, pribadi dan golongannya demi kepentingan negara yang jauh lebih besar, dan lebih tinggi.

\footnotetext{
${ }^{21}$ https://www.kompasiana.com/pedrag1999/5a70 6fee16835f11885c1402/menjadi-seorangnegarawan-yang-baik?page=all
}

Sosok negarawan bukan hanya sematamata menjaga citra yang baik di tengahtengah masyarakatnya. Sebab apabila kita selalu berhitung terhadap citra, maka kita tidak dapat berbuat apa-apa. Ciri dan sifat negarawan tersebut sesungguhnya tersirat didalam tugas berkaitan erat dengan sikap imparsial atau tidak memihak hakim baik dalam pemeriksaan maupun dalam pengambilan keputusan. Kebebasan hakim tersebut tidak bersifat mutlak karena tentu saja dibatasi oleh hukum dan keadilan. Hakim memiliki kebebasan dalam melaksanakan tugasnya secara judicial dan hanya bertanggung jawab kepada Tuhan. Kebebasan hakim secara fungsional melekat dengan pertanggungjawaban (accountability) yang terbuka kepada masyarakat, sehingga hakim tidak hanya mempertanggungjawabkan pelaksanaan kebebasan fungsionalnya pada Tuhan. Independensi dan imparsialitas terutama menjadi lebih penting jika dihadapkan dengan kekuatan politik yang berpengaruh dari pihak yang mengangkat atau memilih hakim.

\section{PENUTUP}

Semua Hakim harus memiliki kualitas kenegarawanan bukan hanya 
Barhamudin dan Abuyazid Bustomi, Kemandirian Hakim dalam Perspektif Negarawan, Halaman 269-284

hakim Konstitus saja, bahkan para hakim itu harus bersikap dan berprilaku sebagai seorang negarawan, oleh karena hakim dituntut tidak memihak atau independen dalam tugasnya menegakan kebenaran yang didasarkan hukum dan keadilan. Hakim harus memiliki pengetahuan dan keahlian penyelenggaraan negara, medan pengalaman yang cukup, serta komitmen untuk melaksanakan dan mengawal kehidupan bernegara sesuai dengan koridor konstitusi. Para hakim itu pada hakikatnya adalah negarawan, jika dilihat dari tugas dan fungsinya menegakan hukum dan keadilan, bukan untuk kepentingan yang lain selain dari untuk kepentingan negara, bukankah unsur negara itu tercermin dari kepentingan rakyat. Hakim memiliki kebebasan dalam melaksanakan tugasnya secara judicial dan hanya bertanggung jawab kepada Allah Tuhan Yang Maha Esa.

\section{DAFTAR PUSTAKA}

Amiruddin, Pengantar Metode Penelitian Hukum, Jakarta: Raja Grafindo Persada, cat-6, 2012.

Ahmad Mujahidin, Peradilan Satu Atap di Indonesia, Bandung: Refika Aditama, 2007.
Departemen Agama RI, Al-Qur`an dan Terjemah, Jakarta: Maghfiro Pustaka, 2006.

Jimly Asshiddiqie, Pokok-pokok Hukum

Tata Negara Indonesia, Jakarta:

Buana Ilmu Populer, 2007.

-----, Pokok Pikiran tentang

Penyempurnaan Sistem

Pengangkatan dan Pemberhentian

Hakim Indonesia.

Josef M. Monteiro, Lembaga-lembaga

Negara Setelah Amandemen UUD 1945, Yogyakarta: Pustaka Yustisia, 2014.

Moh. Mahfud MD, Dasar dan Struktur Ketatanegaraan Indonesia, Jakarta: Rineka Cipta, 2000.

Kamus Besar Bahasa Indonesia, Jakarta: Gramedia Pustaka Utama, 2008, Edisi IV.

Mas'ud Khasan Abdul Qahar, Kamus Ilmiah. Populer, Jakarta: Bulan Bintang, 1989.

Miriam Budiardjo, Dasar-Dasar Ilmu Politik, Jakarta: Gramedia Pustaka Utama, 2008.

Rimdan, Kekuasaan Kehakiman, Jakarta: Kencana Prenada Media Grup, 2012. Wildan Suyuti Mustofa, Kode Etik Hakim, Jakarta: Kencana, 2013. https://kastara.id/27/02/2019/mencari-

hakim-negarawan-yang-ideal/ 
Barhamudin dan Abuyazid Bustomi, Kemandirian Hakim dalam Perspektif Negarawan, Halaman 269-284

https://www.kompasiana.com/pedrag199 Undang-Undang Nomor 48 Tahun 2009

9/5a706fee $16835 \mathrm{f} 11885 \mathrm{c} 1402 / \mathrm{menj}$

tentang Kekuasaan Kehakiman

adi-seorang-negarawan-yang-

baik?page=all 